The Geneva Papers on Risk and Insurance, 20 (No. 74, January 1995) 30-44

\title{
Financing of Insurance Companies
}

\author{
by E.C. Lekkerkerker* and J.F.M. Peters**
}

\section{Introduction}

This article on the financing of insurance companies will first discuss a number of aspects of capital: its function (para 2.1), the various forms in which it can be obtained (para 2.2) and the development of the solvency requirements which insurers must meet (para. 2.3).

Next, we consider the use of debt by insurance companies (para. 3.1) and, in particular, we focus on the financing of mortgages linked to life insurance policies (para. 3.4) and of investments (para. 3.2).

Finally, para. 4 deals with a number of aspects connected with financing an acquisition of a life insurance company.

\section{Risk-bearing capital}

\subsection{The function of risk-bearing capital}

The nature of an insurance company's activities does not, in principle, necessitate the use of additional funding or capital. Premiums are paid before the company has to pay out. Therefore, for insurance companies, risk-bearing capital is not so much used for financing but serves as a buffer, available in the case of disasters.

In the past, ${ }^{1}$ risk-bearing capital - e.g. in the case of a "mutual insurance company" was provided by the members of the mutual company.

At the start of each financial year a provisional contribution was collected from the members insured to cover normal losses, while also a buffer was created for disasters for instance by charging members a kind of "admission fee". If the buffer or capital proved inadequate to pay for excessive claims due to disasters, an additional levy was imposed on members.

* Senior Vice President Group Treasurer, AEGON nv, The Hague.

** Former Chairman, AEGON nv.

${ }^{1}$ See: H. van Barneveld, Algemene Assurantiekennis (General insurance knowledge), seventh edition 1970, p. $94 \mathrm{f}$. 
Before World War II there was a similar system in which insurance companies used partly paid-up registered stock. ${ }^{2}$ The buffer for excessive claims was formed by the obligation on the part of the shareholders to pay up the share in full, if necessary, which increased the risk-bearing capital.

The structure of the risk-bearing capital of Lloyd's (the London insurance market) is partly modelled along these lines too, by the system of members or "names": in addition to the normal premiums received, there is a buffer in the form of the personal assets of the "names".

However, the principle whereby individuals are held liable for losses incurred - which often only are known after several years - can only work as long as the level of risk can to some extent be estimated.

Other factors limiting the expansion of an insurance company's activities are that either the total potential claims on the backing individuals become excessive, or the initial costs associated to expanding activities (such as sales, marketing and automation costs, and costs entailed by the desired broadening of the product range) can no longer be borne by the members.

In addition, it becomes increasingly difficult to monitor the credit-worthiness of members or shareholders. There is a danger that they may subsequently prove to have insufficient assets to bear their part of the risk or to pay up their share in full. In the present crisis on the London insurance market, members are regularly declared bankrupt because they can no longer meet their commitments. It is therefore not surprising that the management of Lloyd's recently decided that it would also admit companies with a limited liability as "names".

In order to counter the drawbacks of partly paid-up stock, the Dutch insurance market in 1950 switched to a system in which shareholders had to pay up the unpaid part in return for a remuneration (annual dividend). An additional advantage of this system was that it facilitated issuance of new shares and the creation of more easily marketable paper.

A number of mutual insurance companies also took steps to secure the capital for their future growth.

Thus, for example, the large American mutual, Equitable Life, gained access to the capital markets by exchanging its mutual status for that of a corporation in 1991.4

Another example is the cooperation between the listed insurance company AEGON N.V. and the British mutual insurance company Scottish Equitable, announced in April 1993. ${ }^{5}$ This involved transferring all activities of Scottish Equitable to a newly established PLC in which AEGON, though wholly owning it in legal terms, initially obtains $40 \%$ of the profit rights from the fast-growing unit-linked activities (which do not normally belong to

2 See: B.P. A. Gales, Werken aan Zekerheid (Improving Security), 1986, p. 317.

${ }^{3}$ See for example Financial Times, International Herald Tribune and Wall Street Journal of 14 September 1993. See also: Lloyd's of London Corporate Capital - making it work, UBS Global Research, September 1993.

${ }^{4}$ See press release by Equitable Life Assurance Society of the US, dated 19 July 1991. See also: Prospectus offering 43.5 million shares, dated 15 July 1992.

${ }^{5}$ See Scottish Equitable - AEGON partnership prospectus, dated 28 May 1993. 
a mutual's product range). The traditional with-profits policies remain in a unit which is separate from the rest of the PLC and in fact continues to operate as a mutual insurance company.

This arrangement means that mutual policyholders in fact capitalize part of their successful investment in unit-linked activities without affecting the character of the mutual structure with regard to the traditional policies.

In comparison with the past, it can be said that insurance companies now not only need risk-bearing capital to cover the consequences of catastrophes, but also require increasing amounts of equity to finance their expansion. Apart from writing off the goodwill payable, capital must also be able to cover extra risks associated with (international) expansion.

Examples hereof are foreign exchange risks and additional buffers to finance initial losses connected with new (foreign) activities. The sharply increased volatility of the equity and bond markets and the resulting fluctuations in the valuation of shares and property portfolios compel insurers to make additional provisions. There are also new threats such as AIDS, environmental pollution and the increased risks of insolvency among reinsurers.

\subsection{Forms of risk-bearing capital}

Up to the time when the life insurance market in the Netherlands began to expand (after World War II), the autonomous growth of the companies could be readily financed by profit retention.

Soon after the life insurance companies began to expand rapidly, additional equity was needed. The traditional method of financing growth - retaining earnings - was no longer adequate for continued compliance with the solvency requirements associated with the sharp rise in turnover ${ }^{6}$ and additional market risks. Paragraph 2.1 explained briefly that one way of obtaining additional equity was payment of existing shares in full. Subsequently this was also achieved by the private placement of new shares or the issuance of new shares on the domestic public capital market. Insurers also increasingly make use of foreign capital markets to strengthen their risk-bearing capital.

The table on page 33 shows capital issues by three major Dutch insurance companies since 1975.

Apart from an increase in equity by the issuance of new shares, the range of options for obtaining new risk-bearing capital is constantly expanding.

As may be seen from the table, various derivates of share issuance have emerged (known as hybrids).

The common feature of all these structures, ${ }^{7}$ such as bonds convertible into ordinary shares, warrants on new shares, preference shares (convertible into ordinary shares) etc., is that they (can) (eventually) increase the risk-bearing capital of the company.

Thus, hybrids give investors the opportunity to participate in the risk-bearing capital of insurers by means of other instruments than ordinary shares. Whether the investor prefers ordinary shares or a hybrid instrument will depend largely on his risk tolerance and fiscal status.

${ }^{6}$ See : E. C. Lekkerkerker, Financieringsproblematiek van de internationaal opererende verzekeringsmaatschapij (Financing issues of the international insurance). Het Verzekerings-Archief 1986/1.

${ }^{7}$ See : R. A. Brealy/S. C. Myers, Principles of Corporate Finance, Third Edition 1988, p. 303 f. 
Table 1: Strengthening of risk bearing capital

Year Nationale Nederlanden/ING

1975

1976 NLG $70 \mathrm{~m}$ rights issue

1977

$1978 \quad$ NLG 127 m rights issue

1979

1980

1981

1982

1983

1984

$1985 \quad$ NLG $528 \mathrm{~m}$ rights issue

1986

$1987 \quad$ NLG 29 m exercise of share warrants

$1988 \quad$ NLG 29 m exercise of share warrants

$1989 \quad$ NLG 683 m rights issue of shares

$1990 \quad$ NLG $22 \mathrm{~m}$ private placement of shares

1991 Issue of 253 million warrants on shares

$1993 \quad$ NLG 653 m preference shares

1994

Source: Annual reports / press releases
ENNIA/AEGON

NLG $27 \mathrm{~m}$ rights

issue / offering

GBP $5 \mathrm{~m}$ convertible

USD $35 \mathrm{~m}$ convertible (subordinated)

NLG $21.7 \mathrm{~m}$ private placement of shares

NLG $34.5 \mathrm{~m}$ private placement of shares (UK)

SFR $100 \mathrm{~m}$ convertible (subordinated)
AMEV-VSB/Fortis

NLG $40 \mathrm{~m}$ rights issue

NLG 35 m rights issue

NLG $43.5 \mathrm{~m}$ rights issue

NLG $116 \mathrm{~m}$ rights issue

NLG $87.5 \mathrm{~m}$ rights issue

USD $60 \mathrm{~m}$ USA

share offering

NLG $321 \mathrm{~m}$ rights issue

SFR $310 \mathrm{~m}$ convertible (subordinated)

NLG $310 \mathrm{~m}$ rights

NLG $282 \mathrm{~m}$ private issue of shares placement of shares

USD $370 \mathrm{~m}$ convertible (subordinated)

NLG $68 \mathrm{~m}$ private placement of shares
USD $600 \mathrm{~m}$ convertible (subordinated) 
Table 2:

Summary of annual dividend offered in the form of ordinary shares as a percentage of oustanding share capital

Year

Nationale

Nederlanden/ING

ENNIA/AEGON

AMEV-VSB /

Fortis

1987 Interim dividend

$2.0 \%$

Final dividend

$3.0 \%$

$2.2 \%$

$1.7 \%$

1988 Interim dividend

$3.0 \%$

Final dividend

$2.75 \%$

$2.5 \%$

$1.7 \%$

$2.5 \%$

1989 Interim dividend

$2.5 \%$

$2.4 \%$

$1.7 \%$

1990 Interim dividend

$2.5 \%$

Final dividend

$2.75 \%$

$3.5 \%$

$1.7 \%$

$2.5 \%$

1991 Interim dividend

$2.5 \%$

$3.5 \%$

$1.7 \%$

1992 Interim dividend

$2.5 \%$

Final dividend

0.22 preference

share

$3.1 \%$

$1.7 \%$

$2.5 \%$

$1.3 \%$

$2.5 \%$

$2.9 \%$

$2.8 \%$

1994 Interim dividend

$2.5 \%$

$1.3 \%$

Source: Annual reports / press releases

Another method which many Dutch companies are using to increase their risk-bearing capital, is to issue shares by declaring a stock dividend. Here, the dividend on existing shares is paid out in whole or in part in the form of new shares. The major Dutch insurers pay out stock dividend to their shareholders too; this enables them to keep the bulk of the year's profit in the company and add to their surplus capital solvency position.

Furthermore, for the Dutch retail shareholder receiving stock dividend is fiscally attractive. (See table 2).

However, the disadvantages of stock dividend are that shares are issued at times when the company does not need to increase its risk-bearing capital position, or when market conditions are unfavorable.

In May 1993, AEGON N.V. adjusted its dividend strategy to overcome these drawbacks.

Essentially, this change gives shareholders the option of taking both the interim and the final dividend wholly in cash or wholly in shares; before the holders have to make their choice the company will make either the cash option or the stock option slightly more attractive than its alternative. The company will make stock dividend more attractive than its cash alternative if there is a need to increase its capital position. If that is not necessary, 
cash dividend will be made more attractive. This new method should be seen as a more flexible form of the traditional optional dividend method whereby, in practice, the value of the stock dividend paid out was always higher than that of the cash alternative.

\subsection{Minimum solvency requirements}

According to the Insurance Supervision Act, an insurance company operating on the Dutch market must have a certain minimum solvency margin. ${ }^{8}$

In general insurance, this margin is set as the highest figure obtained from two calculations: one based on premium income in the preceding financial year and one based on claims in the past three financial years.

For life insurance companies, the minimum solvency requirement is a certain percentage of its insurance provisions. The level of that percentage depends largely on the guarantees embedded in the various insurance products.

With regard to solvency and the method of calculating it, the Dutch law is in line with the EC directives on the subject. ${ }^{9}$

In general Dutch insurance companies more than fulfil the set minimum requirements. Most insurers themselves add additional margins to this minimum solvency margin to serve as an extra buffer. Among other things, these buffers serve to cope with (extreme) fluctuations on equity and foreign exchange markets.

A new development in recent years is that solvency is ascertained not only from the liabilities side of the balance sheet, but also by taking into account the risks associated with the assets side. In the United States, the supervisory authorities on the insurance market have imposed rules (via their umbrella organization, the National Association of Insurance Commissioners) for the allocation of risk-bearing capital to the investment portfolio.

Thus, for each investment category a risk supplement is set on the basis of the expected credit risk (e.g., $0 \%$ risk factor for government loans, $30 \%$ for shares).

A survey by Salomon Brothers ${ }^{10}$ showed that this risk-based method of allocating riskbearing capital according to the quality of assets of insurers in the EC is still in an early stage, however, supervisory authorities on the European insurance market can be expected to follow the model of their American colleagues.

As mentioned before, most Dutch insurers - with their extra buffers - already maintain additional solvency to cope with shocks in the investment portfolio.

Another point is the increasing importance of solvency in the marketing of insurance products. 11

In the United States this is already expressed in the "Claims Paying Ability Ratings" of insurers, something that is expected to spread to Europe, too.

\footnotetext{
8 Insurance Supervision Act, Article 39 (1).

${ }^{9}$ First coordination directive on general insurance, OJEC L 228, 16.8.1973. First coordination directive on life insurance, OJEC L 63, I3.3.1979.

10 See : Salomon Brothers Inc., Capital in Banking and Insurance, April 1993.

1 See: R. van Smeede, Door verscherpte concurrentie.. (As a result of increased competition...), De NBvA Stem, August 1993, p. 17.
} 
Apart from determining the minimum solvency margin, it is also important to define the concept of risk-bearing capital. In other words: how can an insurance company finance the minimum required solvency margin. A uniform definition for EC insurers has been under consideration for some years. It appears that the final arrangement will be similar to the definition of risk-bearing capital already introduced for banks. ${ }^{12}$ This means that insurance companies can attract various forms of risk-bearing capital. As is shown in Appendix 2, preference shares and forms of subordinated (convertible) debt are included under risk-bearing capital to a certain extent, in addition to ordinary shares.

To date, insurers have not made large-scale use of these hybrids. However, there is no doubt that, as the financing cost associated with some of these new capital elements is compared with the cost of issuing shares, companies will make increasing use of these new instruments to finance autonomous growth and acquisitions. In this way, European insurers can reduce their cost of capital. The development in the use of such financing instruments by banks - after the announcement of the Bank for International Settlements guidelines in 1988 - indicates the way in which insurance companies can be expected to use the new financing possibilities. This is shown in the following table.

Table 3:

Issue of TIER $2^{13}$ risk-bearing capital by financial institutions over the period 1988 - February 1993 (in US \$ millions)

\section{TIER2}

$\begin{array}{lrrr}\text { Year } & \begin{array}{c}\text { US } \\ \text { dollar } \\ \text { market }\end{array} & \begin{array}{c}\text { Sterling } \\ \text { market }\end{array} & \text { Total } \\ 1988 & 6887 & 1185 & 8072 \\ 1989 & 9264 & 0 & 9264 \\ 1990 & 8154 & 731 & 8885 \\ 1991 & 6563 & 470 & 7033 \\ 1992 & 28758 & 2008 & 30766 \\ 1993 & * * * * * & * * * * & * * * * \\ \text { ree: Salomon Brothers Inc. } & & & \end{array}$

\section{Debt financing}

\subsection{Usage of debt}

It has emerged ${ }^{14}$ that life insurance companies as a whole in the Netherlands still had no substantial borrowings at the end of 1970. The liabilities side of the balance sheet then consisted almost entirely of the provisions for insurance and (shareholders) equity.

${ }^{12}$ See: Definitions of capital under the current Basle Accord Guidelines; see also Appendix 1.

${ }^{13}$ See Appendix 1 for definitions of risk-bearing capital for banks, Basle Accords.

${ }^{14}$ See : P.C. van der Lugt and J.F.M. Peters, De financiering van het verzekeringsbedrijf (Financing insurance activities), Economie van het Verzekeringsbedrijf, p. $72 \mathrm{f}$. 
Looking at the aggregate balance sheet as per 31 December 1991 for life insurers operating in the Netherlands, as published in the annual report of the Dutch Insurance Control Board for 1991, it appears that $11 \%$ of the balance sheet total already comprises short or long-term debt. ${ }^{15}$

There are a number of reasons why insurance companies have made more use of debt financing in recent years.

In general, it can be stated that insurers make particular use of debt to fund their noninsurance activities. These include consumer credit and mortgage loans. As regards the latter, a distinction should be made between mortgage banks taken over by insurers, such as Westland Utrecht Hypotheekbank and FGH-Bank, and the sale of residential mortgages linked to life insurance ("mortgage-linked life insurance").

Another purpose for which insurers might use debt is the temporary financing of investments ("prefinancing"), until the premiums related to the investments are received.

The financing issues connected with mortgage-linked life insurance and the prefinancing of investments will be discussed in more detail below.

\subsection{Financing of mortgages linked to life insurance}

Insurers have always financed the bulk of the mortgages they sold in the market with premiums. At the end of $1991,19 \%$ on average of the investment portfolio of Dutch life insurers consisted of mortgages. The following table shows the investment in mortgages by life insurers as a percentage of the total investment portfolio.

Table 4: Investments in mortgages 1925 - 1991 for all life insurance companies (as a percentage of total investments)

$\begin{array}{ll}\text { Year } & \\ 1925 & 40 \\ 1930 & 43 \\ 1935 & 40 \\ 1939 & 35 \\ 1945 & 11 \\ 1950 & 13 \\ 1955 & 17 \\ 1960 & 21 \\ 1965 & 28 \\ 1970 & 27 \\ 1975 & 24 \\ 1980 & 25 \\ 1985 & 22 \\ 1990 & 20 \\ 1991 & 19\end{array}$

Source: Annual reports.

40

35

11

13

17

21

28

27

24

25

22

20

19 p. 28.

15 See : Verzekeringskamer (Dutch Insurance Control Board). Financial data on life insurers 1991, 
In order to prevent a disruption in the proportion of mortgages in relation to other investment categories in investment portfolios, but also because demand for mortgages exceeded the available funds, some insurers started to fund some of the mortgages with debt.

A different method of financing mortgages outside the investment portfolio is to offer mortgages to the market in cooperation with banks or pension funds, the latter providing the loan part of the mortgage and the insurers retaining the risk and savings part. This method of financing should in fact be regarded as the forerunner of "mortgage securitization".

Securitization means grouping assets into negotiable securities in such a way that they can be sold on the capital market. ${ }^{16}$ For example, these assets may consist of car loans, credit card receivables and mortgages.

In the US the mortgage-backed securities market is one of the largest segments of the US domestic capital market; at the end of 1992 the issue of such securities totalled approx. US $\$ 3,000$ billion.

Mortgage-backed securities (MBS) and related securitization transactions are useful to the issuers because no demand is made on their debt capacity, which there would be if mortgages were funded with debt. Moreover, by using securitization, the insurer can easily adjust the mix of his investment portfolio, if appropriate. One reason for adjusting the composition of the investment portfolio might be that it no longer matches the insurance liabilities. ${ }^{17}$

For investors, mortgage-backed securities are attractive because of the high credit quality. Such quality is generally attained by government guarantees on the underlying mortgages or over-capitalization of the issuing entity.

This form of off-balance-sheet financing is gradually gaining ground outside the US and in future could also become a useful extension of the range of financing instruments for insurers in the Netherlands.

\subsection{Investment finance}

Another reason why insurers borrow funds is to prefinance investments. This means raising debt to finance investments in anticipation of premiums. Current fixed rate investment levels are then fixed for premiums not yet received. Thus, in principle the derived financing requirements are temporary, i.e. within a certain period the debt is repaid using premiums received.

At times when interest rates are expected to fall, insurers tend to pre-invest, while when an increase of interest rates is expected, investment will be postponed and therc will therefore be liquidity surpluses.

${ }^{16}$ See: T. S. Campbell, Money and Capital Markets, 1988, p. 400 f.

17 On the question of Asset and Liability Management (ALM), see also Chapter X of this book: Ontwikkelingen in de Beleggingsleer en de invloed op het Beleggingsbeleid van Nederlandse pensioenfondsen en verzekeringsmaatschappijen (Developments in Investment Theory and the Influence on the Investment Strategy of Dutch Pension Funds and Insurance Companies), by R. A. H. van der Meer and J.F.J. de Munnik. 
Owing to the temporary nature of pre-investment, the appropriate instruments for financing it are short term loans and commercial paper. In recent years there has also been growing use of off-balance-sheet instruments, in order to respond to expected interest rate falls and rises.

The best known products of this type are futures. ${ }^{18}$ Under a futures contract, two parties undertake to sell and buy on a future transaction date a (notional) investment of fixed size, maturity and yield. On this transaction date generally only the value of the contract is settled between the two parties. By the agreement to deliver the underlying security to each other, a transaction is concluded without any direct cash flows taking place. This means that the insurer needs not call on his borrowing capacity.

However, the result of entering into buying/selling futures and pre-investment has the same effect.

We can conclude that insurers currently have adequate (off-balance-sheet) instruments for ensuring the desired interest rate levels - as they do for financing mortgages.

\section{Financing acquisitions}

In the past ten years the large Dutch insurance groups have expanded particularly strongly outside their original home base. This growth was not only autonomous but certainly also involved acquisitions. This led to international groups with several "home markets" and a "foreign" turnover substantially greater than that generated in the Netherlands.

This international expansion was fostered by the relatively small size of the Dutch insurance market, the strong solvency position of Dutch insurance groups and the attractive growth opportunities elsewhere.

In view of this we devote a separate paragraph to questions associated with the financing of acquisitions.

When a life insurance company is taken over, the goodwill initially plays an important role. This is because life insurance contracts are usually concluded for long periods during which an annual profit margin is secure - provided that assets and liabilities are well matched. In other words: the cash value of future profits on the existing portfolio is an important component of the purchase price payable, in view of the long duration of life insurance contracts.

Another component of "goodwill" is the value of the structure for the conclusion of new life insurances, also known as the structure value. This is the cash value of potential future profits on insurances to be concluded in the future.

The purchase price payable will thus consist of the visible equity, the cash value of profits on the existing portfolio and the value of potential contracts to be concluded in the future. The first two components are also called embedded value, while appraisal value is the term used if the value of new production is also included. ${ }^{19}$

${ }^{18}$ See : W.F. Sharpe / G.J. Alexander, Investments, Fourth edition 1990, p. 594 f.

${ }^{19}$ See : Embedded Value Accounting, lecture by Dr. R. A. H. van der Meer, Erasmus University, Rotterdam, dated 7 June 1990. 
This means that a variable proportion of the purchase price consists of goodwill, which in the Netherlands is generally charged outright to the equity of the company making the take-over. Another method is to write off the purchased goodwill over a number of years via the Profit and Loss account.

In addition, the new owner will have to allocate part of his surplus capital to the newly acquired business in order to meet the solvency requirements. This twofold claim on the surplus capital - writing off the goodwill and allocation of equity - means that sufficient risk-bearing capital must be available to cover it. In paragraphs 2.2 and 2.3 we stated that the amount of risk-bearing capital can be increased not only by issuing ordinary shares but also by means of other instruments.

Acquisitions outside the Netherlands entail exchange rate risks as well. The question of exchange rates focuses on the book value of the company taken over, because we can generally assume that the assets and liabilities of the insurer being taken over will be in the same currency.

In our view, the exchange rate risk relating to the book value of a foreign subsidiary is part of the entrepreneurial risk of companies operating internationally. In other words, the equity of the parent company is subject to fluctuations because it has foreign subsidiaries.

This exchange rate risk is a logical consequence of the decision to operate internationally, and, in general, will therefore not be covered. In order to cater for the consequences of extreme fluctuations in the capital, extra buffers are often formed, as discussed in paragraph 2.3 .

Apart from the exchange rate risk on the book value, there is a translation risk on the profit earned abroad. This risk can be covered in a variety of ways, such as creation of costs in the same currency at the parent company, forward exchange transactions, currency options etc. In general, it can be said that exchange rate risks in the profit and loss accounts of insurers are easier to control than in the case of industrial companies incurring costs in a currency different from that in which profits are made.

\section{Final conclusion}

The financing of insurance companies has undergone a major change: from partly paid-up registered shares to detailed solvency rules at national and European levels, plus the possibility of using numerous new financing instruments.

This development is not surprising in view of the vast expansion in the insurance industry since World War II.

Minimum solvency requirements have also developed over the years into a sophisticated system of rules which also take account of investment risks.

Since insurers sell security, financial soundness is essential: rating agencies will play an increasingly important role in Europe in advising the public on this. The solvency position is becoming an increasingly important distinguishing factor, as has long been the case on the American market.

Although insurers are not (necessarily) major users of debt by nature, they can now strengthen their balance sheets further by securitization and other off-balance-sheet instruments. 
Proper balance sheet management also implies a strict internal dividend policy, so that surplus capital is always available for acquisitons.

For this purpose it is not only necessary to release equity: an acquisition also leads to a drain on resources in the form of writing off goodwill. Finally, good relations with financiers - which also means a flexible form of external dividend policy - ensure that the solvency position can be strengthened again if desired.

\section{Enclosures :}

\section{Appendix 1:}

Definitions of capital under the current Basle accord guidelines

\section{Appendix 2:}

EC directives on own funds 


\section{APPENDIX 1: \\ Definitions of capital under the current Basle accord guidelines}

Tier 1

- Issued and fully paid ordinary shares/common stock and perpetual nonredeemable noncumulative preference shares.

- Disclosed reserves, including retained earnings and surplus such as general and legal reserves. Consolidated accounts may include minority interests in the equity of subsidiaries that are less than wholly owned.

- Deductions from Tier 1 capital include goodwill and intangible assets.

Tier 2

- Undisclosed reserves (accumulated hidden after-tax surplus).

- Revaluation reserves : fixed assets (property); and change in value of long-term holding of equities.

- General provisions that are held against possible future losses. These are limited to $1.25 \%$ of risk-weighted assets.

- Hybrid capital instruments that have the following characteristics: unsecured, subordinated and fully paid : nonredeemable without the prior consent of the supervisory body: available to participate in losses; and allow service obligations to be deferred.

Such instruments are: perpetual cumulative preference shares; certain convertible subordinated bonds; and perpetual subordinated debt.

- Subordinated term debt is divided among the following: dated redeemable preference shares; convertible subordinated bonds not included above ; and unsecured subordinated debt capital with a minimum original fixed term of more than five years. During the past five years of the instrument's life, a cumulative discount factor of $20 \%$ annually will be applied.

The new EC capital adequacy directive includes two additional tiers of capital as follows. ${ }^{1}$

Tier 3

- Short-term subordinated loan capital with the following characteristics : initial maturity of at least two years; and fully paid up and nonredeemable.

Tier 4

- Net trading book profits as at any date other than just the year-end reporting date.

${ }^{1}$ The Bank for International Settlements is considering Tier 3, but it is not giving attention to Tier 4 at this time. 
APPENDIX 2:

$E C$ directives on own funds

Banks

Insurance Companies

Paid-up Capital Plus Share Premium

Accounts.

Perpetual Noncumulative Preference Shares.

Reserves

Retained Earnings

Revaluation Reserves to $1.25 \%$ of total weighted risk assets).
Funds for General Banking Risks (limited

Paid-up capital (or in the case of a mutual, the effective initial fund and any members' account).

One-half of the unpaid share capital or initial fund, once the paid-up capital amounts to $25 \%$ of that share capital or fund.

Reserves (statutory and free), not corresponding to underwriting liabilities.

Retained Earnings

Securities with no specified maturity

Securities of Indeterminate Duration (perpetual cumulative preferred shares and perpetual subordinated debt) which are :

date, including cumulative preferred other than those included above and :

(a) nonredeemable (unless with the consent of the supervising authority):

(a) nonredeemable (unless with the consent of the supervising authority);

(b) option of deferment of interest ;

(b) option of deferment of interest ;

(c) wholly subordinated;

(c) wholly subordinated;

(d) fully paid-up.

(d) fully paid-up.

Fixed-Term Cumulative Preferential

Cumulative Preferred Share Capital, Shares, ranking after all other creditors. including fixed-term preferential share capital, ranking after all creditors.

Subordinated Loan Capital (convertible subordinated bonds and subordinated term loans), ranking after all other creditors and:

Subordinated Loan Capital, ranking after all other creditors and :
(a) fully paid-up;
(a) fully paid-up; 
(b) original maturity of at least five years, or if no fixed repayment, subject to no repayment without five years' notice, except with the supervisor's authority;

(c) during the last five years, the extent to which they rank as own funds must reduce ;

(d) no conditions providing for repayment, other than the winding up of the institution, prior to the agreed repayment date. (b) fixed term must be at least five years and during the last five years must be able to prove the required solvency margin ;

(c) loans with no fixed maturity must be repayable only subject to five years notice except with the consent of the supervising authority;

Uncalled capital and legal commitments from members of cooperatives to make additional nonrefundable payments should the institution incur a loss.

Deductions

(a) intangible assets ;

(b) holdings in other credit and financial institutions of their capital, subordinated claims or similar instruments;

(c) investments in any unconsolidated subsidiaries and associates.

\section{Limitations}

(a) Total of revaluation reserves plus subordinated loan capital plus fixedterm cumulative preferred shares cannot exceed $100 \%$ of paid-up capital plus reserves less the total of own shares held plus intangibles plus material current year losses.

(d) Total of fixed-term cumulative preferred shares plus subordinated loan capital cannot exceed $50 \%$ of paid-up capital plus reserves less the total of own shares held plus intangibles plus material current year losses.
Deductions

Intangibles.

\section{Limitations}

(a) Cumulative preferred share capital plus subordinated loan capital can be a maximum of $50 \%$ of total capital.

(b) Fixed-term subordinated debt and/ or fixed-term cumulative preferred shares cannot exceed $25 \%$ of total capital.

(c) Securities with no specified maturity date plus the subordinated loan capital cannot exceed $50 \%$ of total capital.

Source: Salomon Brothers Inc., The Role of Capital for EC Insurers, May 7, 1993. 